\title{
SEKTOR UNGGULAN DI ERA PANDEMI COVID 19 WILAYAH REGIONAL SUMATERA
}

\author{
Maulana Malik Sebdo Aji ${ }^{1}$, Nuri Nasriyah ${ }^{2}$
}

\begin{abstract}
The Sumatra region is the region with the second largest contribution after Java Island, which experienced a smaller contraction compared to the national figure. The Sumatra region has the opportunity to increase its contribution to the Indonesian economy. The purpose of this study was to analyze the leading sectors in the Sumatra region. The data analysis method used is Location Quotient analysis. The results showed that the Sumatra region in general has advantages in the agricultural and mining sectors. Almost all provinces in the Sumatra region have a competitive advantage in the agricultural sector (only Riau Islands Province which does not have a competitive advantage in the agricultural sector). Only three provinces have a competitive advantage in the manufacturing sector. The three provinces are Riau Province, Bangka Belitung Islands Province and Riau Islands Province. This shows that the processing industry in the Sumatra region has not yet developed or is still inferior to other regions.
\end{abstract}

Keywords: location quotient, economy, sumatera, leading sector

\section{PENDAHULUAN}

Pandemi Virus Covid 19 berdampak buruk bagi keberlangsungan perekonomian dunia tidak terkecuali Indonesia. Covid 19 menyebabkan resesi ekonomi 44 negara di seluruh dunia (CNBC Indonesia, 2020). Perekonomian Indonesia pada kuartal dua tahun 2020 mengalami kontraksi sebesar 5,32 persen jika dibandingkan dengan kuartal dua tahun 2019. Pulau Sumatera sebagai regional wilayah dengan kontribusi perekonomian terbesar kedua setelah Pulau Jawa juga mengalami kontraksi. Namun Provinsi-provinsi di Pulau Sumatera secara keseluruhan mengalami kontraksi lebih rendah dibandingkan nasional (BPS, 2020). Berikut ini adalah grafik pertumbuhan ekonomi year on year provinsi-provinsi di Pulau Sumatera pada kuartal kedua 2020.

\footnotetext{
${ }^{1}$ Corresponding author, Badan Pusat Statistik, maulanamaliksebdoaji@gmail.com

${ }^{2}$ Badan Pusat Statistik, nurin@bps.go.id 


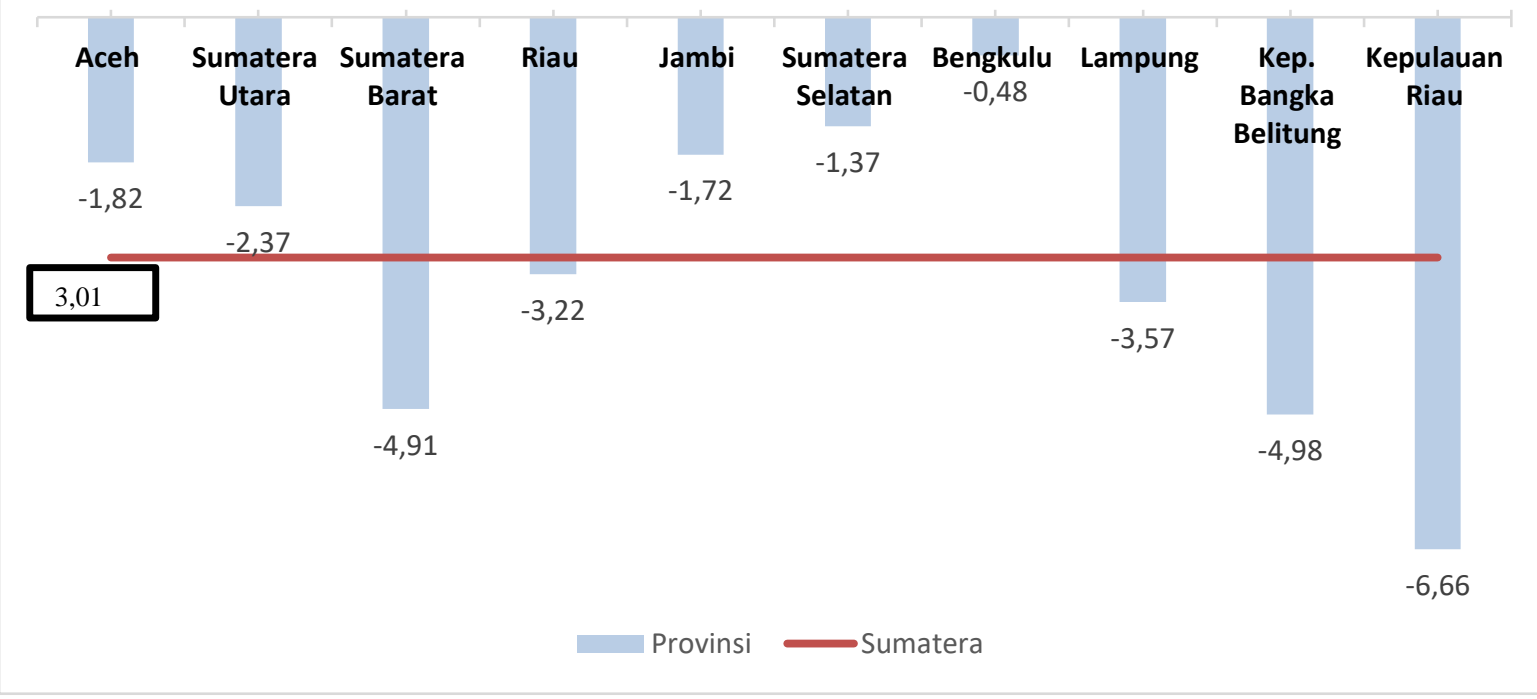

Sumber: Badan Pusat Statistik

Gambar 1. Pertumbuhan Ekonomi Kuartal Dua Tahun 2020 Provinsi-provinsi di Pulau Sumatera

Kontribusi Pulau Sumatera terhadap perekonomian Indonesia sekitar 20 persen (BPS, 2020). Pulau Sumatera kuartal kedua tahun 2020 mengalami kontraksi sebesar minus 3,01 persen. Provinsi di Pulau Sumatera yang mengalami kontraksi paling besar adalah Provinsi Kepulauan Riau (-6,66 persen). Di posisi kedua dan ketiga adalah Provinsi Kepulauan Bangka Belitung (-4,98 persen) dan Provinsi Sumatera Barat (-4,91 persen). Provinsi Bengkulu menjadi wilayah yang mengalami kontraksi paling kecil diantara provinsi-provinsi di Regional Sumatera dengan nilai kontraksi hanya minus 0,48. Data ini menunjukan bahwa hanya Provinsi Kepulauan Riau yang mengalami kontraksi lebih besar dibandingkan angka nasional.

Bervariasinya pertumbuhan ekonomi provinsi-provinsi di wilayah Sumatera menunjukkan kerjasama antar provinsi belum optimal. Kerjasama ekonomi antar provinsi bisa mengurangi ketimpangan pertumbuhan ekonomi antar daerah (Karunia dan Faidah, 2017). Membangun ekonomi yang sedang terpuruk akibat adanya pandemic Covid 19 sangat dibutuhkan sinergi antar wilayah. Kerjasama antar wilayah membutuhkan strategi yang tepat dengan memperhatikan kelemahan dan kekuatan masing-masing wilayah.

Penelitian ini bertujuan untuk menganalisis sektor-sektor unggulan yang dimiliki regional Sumatera. Lebih rinci akan dikaji sektor-sektor unggulan yang dimiliki setiap provinsi di wilayah regional Sumatera. Kajian sektor-sektor unggulan setiap provinsi di regional Sumatera diharapkan bisa menjadi acuan bagi pemerintah provinsi dalam bersinergi.

\section{LANDASAN TEORITIS}

\section{Teori Basis Ekonomi}

Peningkatan pertumbuhan ekonomi dengan menitik beratkan kepada kegiatan ekspor barang ke luar daerah. Wilayah yang memiliki potensi dan kelebihan sumber daya akan 
terus meningkatkan kegiatan ekspor barang ke luar wilayahnya. Dengan begitu, pendapatan daerah akan meningkat dan secara otomatis mendorong pertumbuhan ekonomi yang lebih kuat. Peningkatan ekspor bisa terjadi apabila komoditas yang dihasilkan suatu wilayah sudah cukup berlebih dan memiliki daya saing dibandingkan daerah lainnya (Glasson, 1990).

\section{Penelitian Terdahulu}

Penelitian yang mengkaji tentang sektor unggulan/ daya saing sektor ekonomi menggunakan analisis Location Quotient (LQ) sudah banyak dilakukan. Karunia dan Faidah (2017) meneliti tentang daya saing yang ada di Karisidenan Pekalongan. Karisidenan Pekalongan terdiri dari Kabupaten Pekalongan, Kota Pekalongan, Kota Tegal, Kabupaten Batang, Kabupaten Tegal, Kabupaten Brebes dan Kabupaten Pemalang. Hasil penelitian menunjukan adanya perbedaan sektor unggulan antar wilayah. Temuan hasil penelitian sangat membantu pemerintah daerah dalam hal sinergi antar kabupaten di Karisidenan Pekalongan dalam membangun perekonomian.

Nurlina dkk. (2019) meneliti tentang sektor unggulan wilayah timur Aceh. Wilayah yang diteliti mencakup Kabupaten Aceh Tamiang, Kota langsa dan Kabupaten Aceh Timur. Faisal (2014) meneliti sektor-sektor unggulan yang ada di Kota Banda Aceh. Kota Banda Aceh sebagai Ibu Kota Provinsi Aceh memiliki karakteristik yang berbeda dibandingkan dengan wilayah timur Aceh.

Sari dan Herawaty (2019) mengkaji tentang sektor pertanian unggulan yang ada di Kabupaten Deli Serdang. Dalam penelitiannya, sektor pertanian dijabarkan lebih rinci menjadi sembilan subsektor. Tabrani (2008) sudah melakukan lebih dahulu menghitung sektor-sektor unggul yang ada di Kabupaten Mandailing Natal dengan menampilkan secara rinci menurut subsektor. Bangun (2018) mengkaji sektor-sektor andalan di Kabupaten Tapanuli menggunakan Produk Domestik Regional Bruto (PDRB) 17 sektor.

Nugrohadi dkk. (2015) membahas keunggulan dan daya saing sektor perikanan yang ada di Kabupaten Natuna. Analisis yang disajikan lebih fokus kepada satu wilayah administrasi level kabupaten dan satu sektor. Metode analisis yang digunakan salah satunya adalah analisis LQ. Adhitama ( 2012) menggunakan analisis LQ untuk menghitung sektor ekonomi unggulan kecamatan yang ada di Kabupaten Magelang.

\section{METODE RISET}

Data yang digunakan dalam penelitian ini adalah Produk Domestik Regional Bruto (PDRB) provinsi-provinsi di regional Sumatera dan Produk Domestik Bruto (PDB) Indonesia kuartal 2 tahun 2019 dan 2020 yang berasal dari Badan Pusat Statistik (BPS). Metode analisis data yang digunakan adalah analisis deskriptif berupa gambar dan tabel (Mustafa, 1998). Untuk lebih memperdalam analisis

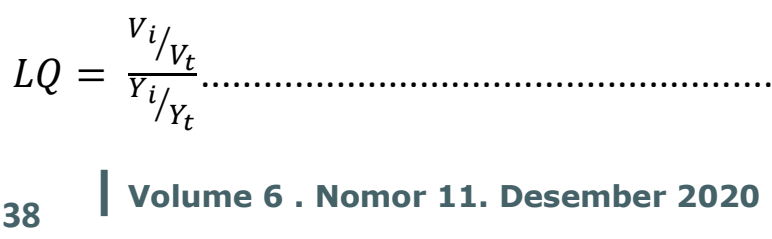


Keterangan:

LQ : Location Quotient

$V_{i} \quad$ : nilai PDRB sektor i pada tingkat wilayah yang lebih rendah

$V_{t} \quad$ : total PDRB pada tingkat wilayah yang lebih rendah

$Y_{i} \quad$ : nilai PDRB sektor i pada tingkat wilayah yang lebih atas

$Y_{t} \quad:$ Total PDRB pada tingkat wilayah yang lebih atas

Nilai LQ dibagi menjadi tiga kategori yang akan dijelaskan dalam tabel berikut ini.

Tabel 1. Kategori Nilai LQ

\begin{tabular}{|c|c|c|}
\hline No & Kategori LQ & Keterangan \\
\hline (1) & (2) & (3) \\
\hline 1 & $\mathrm{LQ}<1$ & $\begin{array}{l}\text { Jika sektor perekonomian suatu wilayah memiliki nilai LQ di bawah } 1 \text { maka bisa } \\
\text { diartikan sektor tersebut tidak memiliki keunggulan komparatif dibandingkan } \\
\text { wilayah lainnya. }\end{array}$ \\
\hline 2 & $L Q=1$ & $\begin{array}{l}\text { Jika sektor perekonomian suatu wilayah memiliki nilai LQ = } 1 \text { maka bisa diartikan } \\
\text { sektor tersebut tidak memiliki keunggulan komparatif dibandingkan wilayah lainnya. }\end{array}$ \\
\hline 3 & $L Q>1$ & $\begin{array}{l}\text { Jika sektor perekonomian suatu wilayah memiliki nilai LQ di atas } 1 \text { maka bisa } \\
\text { diartikan sektor tersebut memiliki keunggulan komparatif dibandingkan wilayah } \\
\text { lainnya. }\end{array}$ \\
\hline
\end{tabular}

Analisis LQ memberikan gambaran keunggulan komparatif sektor-sektor perekonomian provinsi-provinsi di Sumatera terhadap wilayah lainnya. Sehingga dalam penelitian ini, analisis LQ bisa menjadi analisis awal untuk menentukan sektor unggulan provinsi-provinsi di wilayah Sumatera.

\section{ANALISIS DATA DAN PEMBAHASAN}

Kondisi perekonomian saat ini bisa menjadi peluang provinsi-provinsi di regional Sumatera untuk meningkatkan daya saingnya. Selain itu, wilayah regional Sumatera memiliki peran yang cukup besar terhadap perekonomian Indonesia bisa menjadi penyelamat apabila bisa bangkit terlebih dahulu dibandingkan wilayah lainnya. Menurut teori basis ekonomi yang disampaikan (Glasson, 1990), dibutuhkan keunggulan komparatif untuk mendorong aktifitas ekspor suatu wilayah. Pandemi yang disebabkan Covid 19 berpotensi merubah tatanan sektor unggulan di wilayah Sumatera.

Untuk mengetahui pergeseran daya saing sektor-sektor perekonomian di Pulau Sumatera, berikut ini akan disajikan Location Quotient Analysis (LQ Analysis). Untuk lebih rinci analisis daya saing di Pulau Sumatera, akan disajikan setiap provinsi.

\section{Analisis LQ Pulau Sumatera}

Regional Sumatera terdiri dari 10 Provinsi. Delapan provinsi berada di Pulau Sumatera yaitu Provinsi Aceh, Sumatera Utara, Sumatera Barat, Riau, Jambi, Sumatera Selatan, Bengkulu dan Lampung. Terdapat dua provinsi yang berbentuk kepulauan yaitu Provinsi 
Kepulauan Riau dan Provinsi Kepulauan Bangka Belitung. Gabungan hasil perekonomian 10 provinsi tersebut digunakan sebagai dasar penghitungan analisis LQ Pulau Sumatera. Berikut adalah hasil analisis LQ kuartal 2 tahun 2019 dan 2020.

Tabel 2. Hasil Analisis LQ Pulau Sumatera

\begin{tabular}{|c|c|c|c|c|}
\hline No & Sektor & $\begin{array}{c}\text { Nilai LQ Kuartal II } \\
2019 \\
\end{array}$ & $\begin{array}{c}\text { Nilai LQ Kuartal II } \\
2020 \\
\end{array}$ & Keterangan \\
\hline (1) & (2) & (3) & (4) & (5) \\
\hline 1 & Pertanian, Kehutanan, \& Perikanan & 1,62 & 1,59 & Unggulan \\
\hline 2 & Pertambangan \& Penggalian & 1,49 & 1,45 & Unggulan \\
\hline 3 & Industri Pengolahan & 0,95 & 0,98 & \\
\hline 4 & Pengadaan Listrik, Gas & 0,17 & 0,18 & \\
\hline 5 & Pengadaan Air & 0,99 & 0,92 & \\
\hline 6 & Konstruksi & 1,05 & 1,05 & Unggulan \\
\hline 7 & $\begin{array}{l}\text { Perdagangan Besar \& Eceran, \& } \\
\text { Reparasi Mobil \& Sepeda Motor }\end{array}$ & 0,96 & 0,93 & \\
\hline 8 & Transportasi \& Pergudangan & 0,95 & 0,99 & \\
\hline 9 & $\begin{array}{l}\text { Penyediaan Akomodasi \& Makan } \\
\text { Minum }\end{array}$ & 0,49 & 0,48 & \\
\hline 10 & Informasi \& Komunikasi & 0,58 & 0,57 & \\
\hline 11 & Jasa Keuangan & 0,52 & 0,50 & \\
\hline 12 & Real Estate & 0,89 & 0,85 & \\
\hline 13 & Jasa Perusahaan & 0,22 & 0,23 & \\
\hline 14 & $\begin{array}{l}\text { Administrasi Pemerintahan, Pertahanan } \\
\text { \& Jaminan Sosial Wajib }\end{array}$ & 1,02 & 1,04 & Unggulan \\
\hline 15 & Jasa Pendidikan & 0,69 & 0,68 & \\
\hline 16 & Jasa Kesehatan \& Kegiatan Sosial & 0,79 & 0,76 & \\
\hline 17 & Jasa lainnya & 0,41 & 0,39 & \\
\hline
\end{tabular}

Sumber: hasil pengolahan data PDRB

Secara umum berdasarkan tabel 2 terlihat bahwa tidak ada pergeseran signifikan nilai LQ kuartal II tahun 2019 dan 2020. Pandemi Covid19 tidak memberikan dampak yang signifikan terhadap daya saing sektor-sektor ekonomi di Pulau Sumatera. Sektor pertanian, kehutanan, dan perikanan serta sektor pertambangan dan penggalian memiliki nilai LQ lebih besar dari 1 yang menunjukan bahwa kedua sektor tersebut masih menjadi andalan regional Pulau Sumatera. Sektor konstruksi memiliki nilai sedikit lebih dari 1 yang menunjukkan bahwa pembangunan infrastruktur di Pulau Sumatera memiliki nilai rata-rata nasional. Sektor administrasi pemerintahan memiliki nilai LQ = 1,02 pada kuartal 22019 dan naik sedikit menjadi 1,04 pada kuartal 2 2020. Hal ini menunjukan belanja pemerintah di Pulau Sumatera tidak berbeda jauh dengan wilayah lainnya.

\section{Analisis LQ Provinsi Aceh}

Pertumbuhan ekonomi Aceh kuartal 2 tahun 2020 pada pembahasan sebelumnya tercatat sebesar minus 1,32 persen. Meskipun mengalami kontraksi, pertumbuhan ekonomi Provinsi Aceh jauh lebih baik dari angka nasional yang mengalami kontraksi 5,32 persen. Selisih pertumbuhan ekonomi antara Aceh dengan nasional yang cukup besar berpotensi 
menggeser sektor-sektor yang unggul di Provinsi Aceh. Berikut ini adalah hasil dari penghitungan analisis LQ Provinsi Aceh.

Tabel 3. Hasil Analisis LQ Provinsi Aceh

\begin{tabular}{|c|c|c|c|c|}
\hline No & Sektor & $\begin{array}{c}\text { Nilai LQ Kuartal II } \\
2019 \\
\end{array}$ & $\begin{array}{c}\text { Nilai LQ Kuartal II } \\
2020 \\
\end{array}$ & Keterangan \\
\hline (1) & (2) & (3) & (4) & (5) \\
\hline 1 & Pertanian, Kehutanan, \& Perikanan & 2,01 & 1,91 & Unggulan \\
\hline 2 & Pertambangan \& Penggalian & 0,95 & 1,17 & Unggulan \\
\hline 3 & Industri Pengolahan & 0,24 & 0,24 & \\
\hline 4 & Pengadaan Listrik, Gas & 0,15 & 0,17 & \\
\hline 5 & Pengadaan Air & 0,36 & 0,44 & \\
\hline 6 & Konstruksi & 0,79 & 1,01 & Unggulan \\
\hline 7 & $\begin{array}{l}\text { Perdagangan Besar \& Eceran, \& } \\
\text { Reparasi Mobil \& Sepeda Motor }\end{array}$ & 1,17 & 1,12 & Unggulan \\
\hline 8 & Transportasi \& Pergudangan & 1,67 & 1,15 & Unggulan \\
\hline 9 & $\begin{array}{l}\text { Penyediaan Akomodasi \& Makan } \\
\text { Minum }\end{array}$ & 0,45 & 0,47 & \\
\hline 10 & Informasi \& Komunikasi & 0,63 & 0,65 & \\
\hline 11 & Jasa Keuangan & 0,43 & 0,43 & \\
\hline 12 & Real Estate & 1,40 & 1,30 & Unggulan \\
\hline 13 & Jasa Perusahaan & 0,34 & 0,35 & \\
\hline 14 & $\begin{array}{l}\text { Administrasi Pemerintahan, Pertahanan } \\
\text { \& Jaminan Sosial Wajib }\end{array}$ & 2,65 & 2,58 & Unggulan \\
\hline 15 & Jasa Pendidikan & 0,86 & 0,84 & \\
\hline 16 & Jasa Kesehatan \& Kegiatan Sosial & 2,61 & 2,28 & Unggulan \\
\hline 17 & Jasa lainnya & 0,75 & 0,78 & \\
\hline
\end{tabular}

Sumber: hasil pengolahan data PDRB

Hasil penghitungan analisis LQ di Provinsi Aceh menunjukan adanya pergeseran sektor unggulan akibat kondisi pandemic Covid19. Sektor pertambangan berdasarkan data PDRB Aceh kuartal 2 tahun 2019 belum menjadi sektor unggulan bagi Provinsi Aceh. Berdasarkan data PDRB Aceh kuartal 2 tahun 2020, sektor pertambangan sudah menjadi sektor unggulan bagi perekonomian Aceh. Pergeseran juga terjadi di sektor konstruksi dimana nilai LQ berubah dari 0,79 pada tahun 2019 menjadi 1,01 di tahun 2020. Fenomena meningkatnya daya saing sektor konstruksi di Aceh dikarenakan adanya pembangunan tol Banda AcehPidie (CNN, 2020). Sektor Administrasi Pemerintahan dan Jasa Kesehatan memiliki nilai LQ yang tinggi, hal ini dipengaruhi oleh besarnya dana otonomi khusus yang diterima Provinsi Aceh setiap tahunnya. Hasil penghitungan analisis LQ di Provinsi Aceh sejalan dengan penelitian Nurlina dkk.(2019) yang menemukan bahwa wilayah Aceh bagian timur memiliki keunggulan pada sektor pertanian dan sektor pertambangan. Keunggulan komparatif untuk sektor perdagangan besar dan sektor pengangkutan dan komunikasi mendapat dukungan dari penelitian yang dilakukan Faisal (2014). Faisal berhasil menemukan sektor yang memiliki keunggulan di Kota Banda Aceh antara lain sektor perdagangan besar dan sektor pengangkutan dan komunikasi.

Berbeda dengan hasil analisis LQ untuk wilayah Sumatera yang hanya menghasilkan sektor pertanian dan pertambangan sebagai sektor unggulan wilayah Sumatera, hasil 
analisis LQ di Provinsi Aceh menunjukan beberapa sektor merupakan unggulan. Terdapat 8 sektor yang memiliki nilai LQ lebih dari 1 sedangkan 9 sektor lainnya memiliki nilai LQ kurang dari 1.

\section{Analisis LQ Provinsi Sumatera Utara}

Berikut ini adalah hasil dari analisis LQ Provinsi Sumatera Utara.

Tabel 4. Hasil Analisis LQ Provinsi Sumatera Utara

\begin{tabular}{|c|c|c|c|c|}
\hline No & Sektor & $\begin{array}{l}\text { Nilai LQ Kuartal II } \\
2019 \\
\end{array}$ & $\begin{array}{l}\text { Nilai LQ Kuartal II } \\
2020 \\
\end{array}$ & Keterangan \\
\hline$(1)$ & $(2)$ & (3) & (4) & (5) \\
\hline 1 & Pertanian, Kehutanan, \& Perikanan & 1,77 & 1,72 & Unggulan \\
\hline 2 & Pertambangan \& Penggalian & 0,17 & 0,17 & \\
\hline 3 & Industri Pengolahan & 0,83 & 0,86 & \\
\hline 4 & Pengadaan Listrik, Gas & 0,13 & 0,14 & \\
\hline 5 & Pengadaan Air & 1,13 & 1,06 & Unggulan \\
\hline 6 & Konstruksi & 1,25 & 1,23 & Unggulan \\
\hline 7 & $\begin{array}{l}\text { Perdagangan Besar \& Eceran, \& } \\
\text { Reparasi Mobil \& Sepeda Motor }\end{array}$ & 1,31 & 1,34 & Unggulan \\
\hline 8 & Transportasi \& Pergudangan & 1,10 & 1,23 & Unggulan \\
\hline 9 & $\begin{array}{l}\text { Penyediaan Akomodasi \& Makan } \\
\text { Minum }\end{array}$ & 0,78 & 0,83 & \\
\hline 10 & Informasi \& Komunikasi & 0,51 & 0,48 & \\
\hline 11 & Jasa Keuangan & 0,69 & 0,65 & \\
\hline 12 & Real Estate & 1,41 & 1,36 & Unggulan \\
\hline 13 & Jasa Perusahaan & 0,47 & 0,48 & \\
\hline 14 & $\begin{array}{l}\text { Administrasi Pemerintahan, Pertahanan } \\
\text { \& Jaminan Sosial Wajib }\end{array}$ & 0,95 & 0,99 & \\
\hline 15 & Jasa Pendidikan & 0,65 & 0,63 & \\
\hline 16 & Jasa Kesehatan \& Kegiatan Sosial & 0,81 & 0,73 & \\
\hline 17 & Jasa lainnya & 0,27 & 0,28 & \\
\hline
\end{tabular}

Sumber: hasil pengolahan data PDRB

Hasil analisis LQ menunjukan terdapat enam sektor unggulan yang dimiliki Provinsi Sumatera Utara. Sektor tersebut yaitu sektor pertanian, kehutanan, dan perikanan, sektor pengadaan air, sektor konstruksi, sektor perdagangan besar dan eceran, dan reparasi mobil dan sepeda motor, sektor transportasi dan pergudangan, dan sektor real estate. Provinsi Sumatera Utara tidak memiliki keunggulan komparatif dalam sektor industri pengolahan dan sektor pertambangan dan penggalian namun unggul dalam sektor perdagangan besar. Hasil ini sejalan dengan penelitian yang dilakukan oleh Bangun (2018) di Kabupaten Tapanuli Tengah, Tabrani (2008) di Mandailing Natal dan Sari \& Bangun ( 2019) di Kabupaten Deli Serdang

Kondisi ini memberikan gambaran bahwa Provinsi Sumatera Utara menjadi titik sentral perdagangan untuk beberapa wilayah di Pulau Sumatera. Letak geografis di antara Provinsi Aceh, Provinsi Riau dan Provinsi Sumatera Barat menjadi faktor penting berkembangnya sektor perdagangan besar di Provinsi Sumatera Utara. Pertumbuhan 
ekonomi Provinsi Sumatera Utara pada kuartal 2 tahun 2020 mengalami kontraksi namun keadaan tersebut tidak merubah sektor unggulan yang dimiliki wilayah ini.

\section{Analisis LQ Provinsi Sumatera Barat}

Berikut ini adalah hasil dari analisis LQ Provinsi Sumatera Barat.

Tabel 5. Hasil Analisis LQ Provinsi Sumatera Barat

\begin{tabular}{|c|c|c|c|c|}
\hline No & Sektor & $\begin{array}{c}\text { Nilai LQ Kuartal II } \\
2019 \\
\end{array}$ & $\begin{array}{c}\text { Nilai LQ Kuartal II } \\
2020 \\
\end{array}$ & Keterangan \\
\hline (1) & $(2)$ & (3) & (4) & (5) \\
\hline 1 & Pertanian, Kehutanan, \& Perikanan & 1,57 & 1,55 & Unggulan \\
\hline 2 & Pertambangan \& Penggalian & 0,53 & 0,52 & \\
\hline 3 & Industri Pengolahan & 0,42 & 0,44 & \\
\hline 4 & Pengadaan Listrik, Gas & 0,11 & 0,10 & \\
\hline 5 & Pengadaan Air & 1,10 & 1,05 & Unggulan \\
\hline 6 & Konstruksi & 0,91 & 0,91 & \\
\hline \multirow[t]{2}{*}{7} & Perdagangan Besar \& Eceran, \& & & & \multirow{2}{*}{ Unggulan } \\
\hline & Reparasi Mobil \& Sepeda Motor & 1,18 & 1,23 & \\
\hline 8 & Transportasi \& Pergudangan & 2,86 & 2,93 & Unggulan \\
\hline \multirow[t]{2}{*}{9} & Penyediaan Akomodasi \& Makan & & & \\
\hline & Minum & 0,36 & 0,31 & \\
\hline 10 & Informasi \& Komunikasi & 1,36 & 1,37 & \multirow[t]{4}{*}{ Unggulan } \\
\hline 11 & Jasa Keuangan & 0,67 & 0,66 & \\
\hline 12 & Real Estate & 0,65 & 0,66 & \\
\hline 13 & Jasa Perusahaan & 0,23 & 0,25 & \\
\hline \multirow[t]{2}{*}{14} & Administrasi Pemerintahan, & & & \multirow{2}{*}{ Unggulan } \\
\hline & Pertahanan \& Jaminan Sosial Wajib & 1,68 & 1,66 & \\
\hline 15 & Jasa Pendidikan & 1,26 & 1,28 & Unggulan \\
\hline 16 & Jasa Kesehatan \& Kegiatan Sosial & 1,19 & 1,21 & Unggulan \\
\hline 17 & Jasa lainnya & 0,94 & 0,87 & \\
\hline
\end{tabular}

Sumber: hasil pengolahan data PDRB

Hasil analisis LQ menunjukkan bahwa terdapat delapan sektor unggulan yang dimiliki Provinsi Sumatera Barat. Delapan sektor tersebut yaitu sektor pertanian, kehutanan, dan perikanan, sektor pengadaan air, sektor perdagangan besar dan eceran, dan reparasi mobil dan sepeda motor, sektor transportasi dan pergudangan, sektor informasi dan komunikasi, sektor administrasi pemerintahan, pertahanan, dan jaminan sosial wajib, sektor pendidikan, dan sektor jasa kesehatan dan kegiatan sosial. Sektor pertanian, kehutanan, dan perikanan menjadi salah satu sektor unggulan di Provinsi Sumatera Barat. Kondisi ini sejalan dengan penelitian yang dilakukan oleh Martadona dan Leovita (2019). Martadona dan Leovita mengkaji sektor unggulan pertanian di Provinsi Sumatera Barat dengan merinci menurut subsector tanaman pangan. Hasil penelitian menunjukkan komoditas jagung, ubi jalar dan padi sawah merupakan komoditas unggulan di Sumatera Barat.

Provinsi Sumatera Barat sejalan dengan Provinsi Sumatera Utara yang tidak memiliki keunggulan komparatif sektor pertambangan dan sektor industri pengolahan namun unggul dalam sektor perdagangan besar. Pertumbuhan ekonomi Provinsi Sumatera Barat pada 
kuartal 2 tahun 2020 mengalami kontraksi cukup dalam yaitu minus 4,91 persen namun keadaan tersebut tidak merubah sektor unggulan yang dimiliki wilayah ini.

\section{Analisis LQ Provinsi Riau}

Berikut ini adalah hasil dari analisis LQ Provinsi Riau

Tabel 6. Hasil Analisis LQ Provinsi Riau

\begin{tabular}{|c|c|c|c|c|}
\hline No & Sektor & $\begin{array}{c}\text { Nilai LQ Kuartal II } \\
2019 \\
\end{array}$ & $\begin{array}{c}\text { Nilai LQ Kuartal II } \\
2020 \\
\end{array}$ & Keterangan \\
\hline (1) & (2) & (3) & (4) & (5) \\
\hline 1 & Pertanian, Kehutanan, \& Perikanan & 1,83 & 1,83 & Unggulan \\
\hline 2 & Pertambangan \& Penggalian & 2,32 & 2,18 & Unggulan \\
\hline 3 & Industri Pengolahan & 1,42 & 1,51 & Unggulan \\
\hline 4 & Pengadaan Listrik, Gas & 0,06 & 0,08 & \\
\hline 5 & Pengadaan Air & 0,19 & 0,15 & \\
\hline 6 & Konstruksi & 0,85 & 0,84 & \\
\hline 7 & $\begin{array}{l}\text { Perdagangan Besar \& Eceran, \& } \\
\text { Reparasi Mobil \& Sepeda Motor }\end{array}$ & 0,74 & 0,61 & \\
\hline 8 & Transportasi \& Pergudangan & 0,21 & 0,18 & \\
\hline 9 & $\begin{array}{l}\text { Penyediaan Akomodasi \& Makan } \\
\text { Minum }\end{array}$ & 0,16 & 0,11 & \\
\hline 10 & Informasi \& Komunikasi & 0,18 & 0,17 & \\
\hline 11 & Jasa Keuangan & 0,23 & 0,23 & \\
\hline 12 & Real Estate & 0,32 & 0,31 & \\
\hline 13 & Jasa Perusahaan & 0,00 & 0,00 & \\
\hline 14 & $\begin{array}{l}\text { Administrasi Pemerintahan, Pertahanan } \\
\text { \& Jaminan Sosial Wajib }\end{array}$ & 0,51 & 0,49 & \\
\hline 15 & Jasa Pendidikan & 0,17 & 0,17 & \\
\hline 16 & Jasa Kesehatan \& Kegiatan Sosial & 0,17 & 0,19 & \\
\hline 17 & Jasa lainnya & 0,28 & 0,18 & \\
\hline
\end{tabular}

Sumber: hasil pengolahan data PDRB

Hasil analisis LQ menunjukkan bahwa Provinsi Riau hanya unggul pada tiga sektor perekonomian. Tiga sektor ekonomi tersebut yaitu sektor sektor pertanian, kehutanan, dan perikanan, sektor pertambangan dan penggalian, dan sektor industri pengolahan. Alhaq (2017) mengkaji tentang sektor unggulan di Provinsi Riau. Hasil dari penelitian Alhaq menunjukan bahwa sektor pertanian menjadi sektor andalan bagi Provinsi Riau. Lebih rinci, subsektor pertanian yang menjadi andalan Provinsi Riau adalah perkebunan dan kehutanan. Provinsi Riau memiliki lahan perkebunan sawit yang cukup luas. Karakteristik tanah di Provinsi Riau yang cukup mengandung air menjadi daya dukung pengembangan perkebunan sawit di wilayah ini.

Pertumbuhan ekonomi Provinsi Riau pada kuartal 2 tahun 2020 mengalami kontraksi cukup dalam yaitu minus 3,22 persen namun keadaan tersebut tidak merubah sektor unggulan yang dimiliki wilayah ini.

\section{Analisis LQ Provinsi Jambi}

Berikut ini adalah hasil dari analisis LQ Provinsi Jambi. 
Tabel 7. Hasil Analisis LQ Provinsi Jambi

\begin{tabular}{|c|c|c|c|c|}
\hline No & Sektor & $\begin{array}{c}\text { Nilai LQ Kuartal II } \\
2019 \\
\end{array}$ & $\begin{array}{c}\text { Nilai LQ Kuartal II } \\
2020 \\
\end{array}$ & Keterangan \\
\hline (1) & $(2)$ & (3) & (4) & $(5)$ \\
\hline 1 & Pertanian, Kehutanan, \& Perikanan & 1,86 & 1,78 & Unggulan \\
\hline 2 & Pertambangan \& Penggalian & 3,15 & 3,10 & Unggulan \\
\hline 3 & Industri Pengolahan & 0,49 & 0,50 & \\
\hline 4 & Pengadaan Listrik, Gas & 0,05 & 0,05 & \\
\hline 5 & Pengadaan Air & 1,56 & 1,50 & Unggulan \\
\hline 6 & Konstruksi & 0,71 & 0,70 & \\
\hline 7 & $\begin{array}{l}\text { Perdagangan Besar \& Eceran, \& } \\
\text { Reparasi Mobil \& Sepeda Motor }\end{array}$ & 0,75 & 0,75 & \\
\hline 8 & Transportasi \& Pergudangan & 0,74 & 0,77 & \\
\hline 9 & $\begin{array}{l}\text { Penyediaan Akomodasi \& Makan } \\
\text { Minum }\end{array}$ & 0,36 & 0,37 & \\
\hline 10 & Informasi \& Komunikasi & 0,67 & 0,67 & \\
\hline 11 & Jasa Keuangan & 0,52 & 0,52 & \\
\hline 12 & Real Estate & 0,49 & 0,45 & \\
\hline 13 & Jasa Perusahaan & 0,54 & 0,55 & \\
\hline 14 & $\begin{array}{l}\text { Administrasi Pemerintahan, Pertahanan } \\
\text { \& Jaminan Sosial Wajib }\end{array}$ & 1,01 & 0,97 & \\
\hline 15 & Jasa Pendidikan & 1,04 & 1,04 & Unggulan \\
\hline 16 & Jasa Kesehatan \& Kegiatan Sosial & 0,99 & 0,94 & \\
\hline 17 & Jasa lainnya & 0,55 & 0,57 & \\
\hline
\end{tabular}

Sumber: hasil pengolahan data PDRB

Hasil analisis LQ menunjukkan bahwa Provinsi Jambi hanya unggul pada empat sektor perekonomian. Empat sektor ekonomi tersebut yaitu sektor sektor pertanian, kehutanan, dan perikanan, sektor pertambangan dan penggalian, sektor pengadaan air, dan sektor jasa pendidikan. Menurut Yulmardi dan Erfit (2018), sektor pertanian di Provinsi Jambi yang menjadi unggulan berasal dari subsektor tanaman pangan, subsektor perkebunan dan subsektor hortikultura. Mayoritas kabupaten/kota di Provinsi Jambi masih mengandalkan sektor pertanian sebagai sektor unggulan di wilayahnya (Imelia, 2011).

Pandemi Covid 19 sedikit merubah peta sektor unggulan di Provinsi Jambi. Terdapat satu sektor yang tadinya memiliki LQ di atas 1 pada tahun 2019 namun pada tahun 2020 memiliki nilai di bawah 1 . Sektor tersebut adalah sektor administrasi pemerintahan, pertahanan, dan jaminan sosial.

\section{Analisis LQ Provinsi Sumatera Selatan}

Berikut ini adalah hasil dari analisis LQ Provinsi Sumatera Selatan.

Tabel 8. Hasil Analisis LQ Provinsi Sumatera Selatan

\begin{tabular}{ccccc}
\hline No & Sektor & Nilai LQ Kuartal II & Nilai LQ Kuartal II & Keterangan \\
& & $\mathbf{2 0 1 9}$ & $\mathbf{2 0 2 0}$ & (5) \\
\hline $\mathbf{( 1 )}$ & $\mathbf{( 2 )}$ & $\mathbf{( 3 )}$ & $\mathbf{( 4 )}$ & (5) \\
\hline 1 & Pertanian, Kehutanan, \& Perikanan & 1,20 & 1,15 & Ungulan
\end{tabular}


Tabel 8. Hasil Analisis LQ Provinsi Sumatera Selatan (lanjutan)

\begin{tabular}{|c|c|c|c|c|}
\hline No & Sektor & $\begin{array}{c}\text { Nilai LQ Kuartal II } \\
2019 \\
\end{array}$ & $\begin{array}{c}\text { Nilai LQ Kuartal II } \\
2020 \\
\end{array}$ & Keterangan \\
\hline (1) & (2) & (3) & (4) & (5) \\
\hline 2 & Pertambangan \& Penggalian & 2,97 & 2,84 & Unggulan \\
\hline 3 & Industri Pengolahan & 0,87 & 0,90 & \\
\hline 4 & Pengadaan Listrik, Gas & 0,11 & 0,13 & \\
\hline 5 & Pengadaan Air & 1,34 & 1,24 & Unggulan \\
\hline 6 & Konstruksi & 1,13 & 1,14 & Unggulan \\
\hline 7 & $\begin{array}{l}\text { Perdagangan Besar \& Eceran, \& } \\
\text { Reparasi Mobil \& Sepeda Motor }\end{array}$ & 0,77 & 0,74 & \\
\hline 8 & Transportasi \& Pergudangan & 0,47 & 0,58 & \\
\hline 9 & $\begin{array}{l}\text { Penyediaan Akomodasi \& Makan } \\
\text { Minum }\end{array}$ & 0,46 & 0,47 & \\
\hline 10 & Informasi \& Komunikasi & 0,62 & 0,60 & \\
\hline 11 & Jasa Keuangan & 0,57 & 0,54 & \\
\hline 12 & Real Estate & 1,06 & 1,00 & \\
\hline 13 & Jasa Perusahaan & 0,06 & 0,06 & \\
\hline 14 & $\begin{array}{l}\text { Administrasi Pemerintahan, Pertahanan } \\
\text { \& Jaminan Sosial Wajib }\end{array}$ & 0,85 & 0,88 & \\
\hline 15 & Jasa Pendidikan & 0,82 & 0,79 & \\
\hline 16 & Jasa Kesehatan \& Kegiatan Sosial & 0,54 & 0,60 & \\
\hline 17 & Jasa lainnya & 0,41 & 0,49 & \\
\hline
\end{tabular}

Sumber: hasil pengolahan data PDRB

Hasil analisis LQ menunjukkan bahwa Provinsi Sumatera Selatan unggul pada empat sektor perekonomian. Empat sektor ekonomi tersebut yaitu sektor sektor pertanian, kehutanan, dan perikanan, sektor pertambangan dan penggalian, sektor pengadaan air dan sektor konstruksi. Penelitian yang dilakukan oleh Nur dkk. (2018) yang menggunakan data PDRB tahun 2010 menunjukkan hasil tidak berbeda jauh. Sektor pertanian, sektor pertambangan dan sektor konstruksi sudah menjadi sektor unggulan Provinsi Sumatera Selatan sejak tahun 2010. Namun pada tahun 2010, sektor pengadaan air bersih belum menjadi sektor unggulan di Provinsi Sumatera Selatan.

Nilai LQ Provinsi Sumatera Selatan tidak banyak berubah meskipun pertumbuhan ekonomi kuartal 2 tahun 2020 mengalami kontraksi minus 1,37 persen, artinya pandemi Covid 19 tidak membuat pergeseran sektor unggulan di Provinsi Sumatera Selatan.

\section{Analisis LQ Provinsi Bengkulu}

Berikut ini adalah hasil dari analisis LQ Provinsi Bengkulu.

Tabel 9. Hasil Analisis LQ Provinsi Bengkulu

\begin{tabular}{clccc}
\hline No & Sektor & $\begin{array}{c}\text { Nilai LQ Kuartal II } \\
\mathbf{2 0 1 9}\end{array}$ & $\begin{array}{c}\text { Nilai LQ Kuartal II } \\
\mathbf{2 0 2 0}\end{array}$ & Keterangan \\
\hline $\mathbf{( 1 )}$ & \multicolumn{1}{c|}{$(\mathbf{2 )}$} & $\mathbf{( 3 )}$ & $\mathbf{( 4 )}$ & (5) \\
\hline 1 & Pertanian, Kehutanan, \& Perikanan & 1,97 & 1,89 & Unggulan \\
\hline 2 & Pertambangan \& Penggalian & 0,45 & 0,43 & \\
3 & Industri Pengolahan & 0,28 & 0,28 & \\
4 & Pengadaan Listrik, Gas & 0,09 & 0,10 & Unggulan \\
5 & Pengadaan Air & 2,54 & 2,35 &
\end{tabular}


Tabel 9. Hasil Analisis LQ Provinsi Bengkulu (lanjutan)

\begin{tabular}{|c|c|c|c|c|}
\hline No & Sektor & $\begin{array}{c}\text { Nilai LQ Kuartal II } \\
2019 \\
\end{array}$ & $\begin{array}{c}\text { Nilai LQ Kuartal II } \\
2020 \\
\end{array}$ & Keterangan \\
\hline (1) & (2) & (3) & (4) & (5) \\
\hline 6 & Konstruksi & 0,45 & 0,44 & \\
\hline 7 & $\begin{array}{l}\text { Perdagangan Besar \& Eceran, \& } \\
\text { Reparasi Mobil \& Sepeda Motor }\end{array}$ & 1,18 & 1,17 & Unggulan \\
\hline 8 & Transportasi \& Pergudangan & 1,86 & 2,29 & Unggulan \\
\hline 9 & $\begin{array}{l}\text { Penyediaan Akomodasi \& Makan } \\
\text { Minum }\end{array}$ & 0,56 & 0,67 & \\
\hline 10 & Informasi \& Komunikasi & 0,84 & 0,76 & \\
\hline 11 & Jasa Keuangan & 0,72 & 0,76 & \\
\hline 12 & Real Estate & 1,47 & 1,41 & Unggulan \\
\hline 13 & Jasa Perusahaan & 1,17 & 1,23 & Unggulan \\
\hline 14 & $\begin{array}{l}\text { Administrasi Pemerintahan, Pertahanan } \\
\text { \& Jaminan Sosial Wajib }\end{array}$ & 2,57 & 2,55 & Unggulan \\
\hline 15 & Jasa Pendidikan & 1,98 & 1,92 & Unggulan \\
\hline 16 & Jasa Kesehatan \& Kegiatan Sosial & 1,44 & 1,42 & Unggulan \\
\hline 17 & Jasa lainnya & 0,43 & 0,47 & \\
\hline
\end{tabular}

Sumber: hasil pengolahan data PDRB

Hasil analisis LQ menunjukkan bahwa Provinsi Bengkulu unggul pada lima sektor perekonomian. Lima sektor ekonomi tersebut yaitu sektor sektor pertanian, kehutanan, dan perikanan, sektor pengadaan air, sektor perdagangan besar dan eceran, dan reparasi mobil dan sepeda motor, sektor transportasi dan pergudangan, sektor reale estate, sektor jasa perusahaan, sektor administrasi pemerintahan, pertahanan, dan jaminan sosial wajib, sektor pendidikan, dan sektor jasa kesehatan dan kegiatan sosial. Dukungan penelitian dari Pratama dkk. (2017) memberikan informasi lebih rinci mengenai sektor pertanian yang menjadi unggulan Provinsi Bengkulu. Menurut Pratama dkk., hanya subsektor peternakan yang merupakan subsektor unggulan. Subsektor lainnya yang berasal dari sektor pertanian seperti subsektor tanaman bahan makanan, subsektor tanaman perkebunan, subsektor kehutanan dan subsektor perikanan tidak menjadi subsektor pertanian unggulan. Secara umum berdasarkan perbandingan hasil analisis LQ tahun 2019 dan 2020 menunjukkan sektor unggulan Provinsi Bengkulu tidak mengalami perubahan akibat adanya pandemi Covid 19.

\section{Analisis LQ Provinsi Lampung}

Berikut ini adalah hasil dari analisis LQ Provinsi Lampung.

Tabel 10. Hasil Analisis LQ Provinsi Lampung

\begin{tabular}{clccc}
\hline No & Sektor & Nilai LQ Kuartal II & Nilai LQ Kuartal II & Keterangan \\
& & $\mathbf{2 0 1 9}$ & $\mathbf{2 0 2 0}$ & (5) \\
\hline $\mathbf{( 1 )}$ & $\mathbf{( 2 )}$ & $\mathbf{( 3 )}$ & $\mathbf{( 4 )}$ & Unggulan \\
\hline 1 & Pertanian, Kehutanan, \& Perikanan & 2,09 & 2,05 & \\
2 & Pertambangan \& Penggalian & 0,74 & 0,74 & \\
3 & Industri Pengolahan & 0,88 & 0,81 & \\
4 & Pengadaan Listrik, Gas & 0,17 & 0,17 & \\
\hline
\end{tabular}


Tabel 10. Hasil Analisis LQ Provinsi Lampung (lanjutan)

\begin{tabular}{|c|c|c|c|c|}
\hline No & Sektor & $\begin{array}{c}\text { Nilai LQ Kuartal II } \\
2019 \\
\end{array}$ & $\begin{array}{c}\text { Nilai LQ Kuartal II } \\
2020 \\
\end{array}$ & Keterangan \\
\hline (1) & (2) & (3) & (4) & $(5)$ \\
\hline 5 & Pengadaan Air & 1,14 & 1,12 & Unggulan \\
\hline 6 & Konstruksi & 0,91 & 0,93 & \\
\hline 7 & $\begin{array}{l}\text { Perdagangan Besar \& Eceran, \& } \\
\text { Reparasi Mobil \& Sepeda Motor }\end{array}$ & 0,90 & 0,86 & \\
\hline 8 & Transportasi \& Pergudangan & 1,22 & 1,52 & Unggulan \\
\hline 9 & $\begin{array}{l}\text { Penyediaan Akomodasi \& Makan } \\
\text { Minum }\end{array}$ & 0,46 & 0,55 & \\
\hline 10 & Informasi \& Komunikasi & 0,87 & 0,86 & \\
\hline 11 & Jasa Keuangan & 0,47 & 0,47 & \\
\hline 12 & Real Estate & 0,98 & 0,93 & \\
\hline 13 & Jasa Perusahaan & 0,07 & 0,07 & \\
\hline 14 & $\begin{array}{l}\text { Administrasi Pemerintahan, Pertahanan } \\
\text { \& Jaminan Sosial Wajib }\end{array}$ & 0,87 & 0,94 & \\
\hline 15 & Jasa Pendidikan & 0,91 & 0,93 & \\
\hline 16 & Jasa Kesehatan \& Kegiatan Sosial & 0,79 & 0,78 & \\
\hline 17 & Jasa lainnya & 0,47 & 0,47 & \\
\hline
\end{tabular}

Sumber: hasil pengolahan data PDRB

Hasil analisis LQ menunjukkan terdapat tiga sektor unggulan yang dimiliki Provinsi Lampung. Ketiga sektor unggulan tersebut adalah sektor pertanian, kehutanan, dan perikanan, sektor pengadaan air dan sektor transportasi dan pergudangan. Provinsi Lampung tidak memiliki keunggulan komparatif sektor pertambangan maupun sektor industri pengolahan. Astuti dan Sumarlin (2013) mengkaji keunggulan komparatif sektor pertanian di Kabupaten Lampung Barat. Hasilnya adalah komoditas padi, ubi jalar, kacang tanah, dan kacang hijau memiliki keunggulan dibandingkan daerah lainnya. Potensi komoditas pertanian ini belum dioptimalkan Provinsi Lampung untuk mendorong kegiatan industri pengolahan. Pandemi Covid 19 juga tidak merubah komposisi sektor unggulan di Provinsi Lampung.

\section{Analisis LQ Provinsi Kepulauan Bangka Belitung}

Berikut ini adalah hasil dari analisis LQ Provinsi Kepulauan Bangka Belitung.

Tabel 11. Hasil Analisis LQ Provinsi Kepulauan Bangka Belitung

\begin{tabular}{|c|c|c|c|c|}
\hline No & Sektor & $\begin{array}{c}\text { Nilai LQ Kuartal II } \\
2019 \\
\end{array}$ & $\begin{array}{c}\text { Nilai LQ Kuartal II } \\
2020 \\
\end{array}$ & Keterangan \\
\hline (1) & (2) & (3) & (4) & (5) \\
\hline 1 & Pertanian, Kehutanan, \& Perikanan & 1,33 & 1,38 & Unggulan \\
\hline 2 & Pertambangan \& Penggalian & 1,62 & 1,47 & Unggulan \\
\hline 3 & Industri Pengolahan & 1,01 & 1,03 & Unggulan \\
\hline 4 & Pengadaan Listrik, Gas & 0,09 & 0,10 & \\
\hline 5 & Pengadaan Air & 0,20 & 0,20 & \\
\hline 6 & Konstruksi & 0,86 & 0,86 & \\
\hline 7 & $\begin{array}{l}\text { Perdagangan Besar \& Eceran, \& } \\
\text { Reparasi Mobil \& Sepeda Motor }\end{array}$ & 1,05 & 1,02 & Unggulan \\
\hline 8 & Transportasi \& Pergudangan & 0,86 & 0,87 & \\
\hline
\end{tabular}


Tabel 11. Hasil Analisis LQ Provinsi Kepulauan Bangka Belitung (lanjutan)

\begin{tabular}{clccc}
\hline No & \multicolumn{1}{c}{ Sektor } & $\begin{array}{c}\text { Nilai LQ Kuartal II } \\
\mathbf{2 0 1 9}\end{array}$ & $\begin{array}{c}\text { Nilai LQ Kuartal II } \\
\mathbf{2 0 2 0}\end{array}$ & Keterangan \\
\hline $\mathbf{1}$ & \multicolumn{1}{c}{$(\mathbf{2})$} & $\mathbf{( 3 )}$ & $\mathbf{( 4 )}$ & (5) \\
\hline 10 & Informasi \& Komunikasi & 0,41 & 0,43 & \\
11 & Jasa Keuangan & 0,46 & 0,40 & Unggulan \\
\hline 12 & Real Estate & 1,05 & 1,05 & Unggulan \\
13 & Jasa Perusahaan & 0,13 & 0,12 & 1,68 \\
14 & Administrasi Pemerintahan, Pertahanan & 1,69 & 0,80 & \\
& \& Jaminan Sosial Wajib & & 0,94 & \\
15 & Jasa Pendidikan & 0,80 & 0,38 & \\
17 & Jasa Kesehatan \& Kegiatan Sosial & 1,06 & & \\
\hline
\end{tabular}

Sumber: hasil pengolahan data PDRB

Hasil dari analisis LQ menunjukkan Provinsi Kepulauan Bangka Belitung memiliki enam sektor unggulan. Sektor unggulan Provinsi Kepulauan Bangka Belitung adalah sektor Pertanian, kehutanan, dan perikanan, sektor pertambangan dan penggalian, sektor industri pengolahan, sektor perdagangan besar \& eceran, \& reparasi mobil \& sepeda motor dan sektor administrasi pemerintahan, pertahanan,dan jaminan sosial wajib. Widiarsih (2016) mengkaji mengenai perekonomian di Provinsi Bangka Belitung. Hasil penelitian Widiarsih menunjukkan adanya ketidakmerataan sektor unggulan. Bahkan Kota Pangkal Pinang sebagai ibu kota provinsi tidak memiliki keunggulan di sektor pertanian, sektor pertambangan dan sektor industri pengolahan. Secara umum Pandemi Covid 19 merubah satu sektor yang sebelumnya menjadi sektor unggulan menjadi tidak unggulan. Sektor tersebut adalah sektor jasa kesehatan dan kegiatan sosial.

\section{Analisis LQ Provinsi Kepulauan Riau}

Berikut ini adalah hasil dari analisis LQ Provinsi Kepulauan Riau.

Tabel 12. Hasil Analisis LQ Provinsi Kepulauan Riau

\begin{tabular}{|c|c|c|c|c|}
\hline No & Sektor & $\begin{array}{c}\text { Nilai LQ Kuartal II } \\
2019 \\
\end{array}$ & $\begin{array}{c}\text { Nilai LQ Kuartal II } \\
2020 \\
\end{array}$ & Keterangan \\
\hline (1) & (2) & (3) & (4) & (5) \\
\hline 1 & Pertanian, Kehutanan, \& Perikanan & 0,22 & 0,21 & \\
\hline 2 & Pertambangan \& Penggalian & 1,73 & 1,74 & Unggulan \\
\hline 3 & Industri Pengolahan & 1,77 & 1,96 & Unggulan \\
\hline 4 & Pengadaan Listrik, Gas & 0,88 & 0,91 & \\
\hline 5 & Pengadaan Air & 1,59 & 1,38 & Unggulan \\
\hline 6 & Konstruksi & 1,85 & 1,77 & Unggulan \\
\hline 7 & $\begin{array}{l}\text { Perdagangan Besar \& Eceran, \& } \\
\text { Reparasi Mobil \& Sepeda Motor }\end{array}$ & 0,64 & 0,63 & \\
\hline 8 & Transportasi \& Pergudangan & 0,57 & 0,31 & \\
\hline 9 & $\begin{array}{l}\text { Penyediaan Akomodasi \& Makan } \\
\text { Minum }\end{array}$ & 0,77 & 0,43 & \\
\hline 10 & Informasi \& Komunikasi & 0,47 & 0,50 & \\
\hline 11 & Jasa Keuangan & 0,68 & 0,65 & \\
\hline 12 & Real Estate & 0,47 & 0,42 & \\
\hline 13 & Jasa Perusahaan & 0,00 & 0,00 & \\
\hline
\end{tabular}


Tabel 12. Hasil Analisis LQ Provinsi Kepulauan Riau (lanjutan)

\begin{tabular}{clccc}
\hline No & \multicolumn{1}{c}{ Sektor } & $\begin{array}{c}\text { Nilai LQ Kuartal II } \\
\mathbf{2 0 1 9}\end{array}$ & $\begin{array}{c}\text { Nilai LQ Kuartal II } \\
\mathbf{2 0 2 0}\end{array}$ & Keterangan \\
\hline $\mathbf{1}(\mathbf{1}$ & \multicolumn{1}{c}{$(\mathbf{2})$} & $\mathbf{( 3 )}$ & $\mathbf{( 4 )}$ & (5) \\
\hline 14 & Administrasi Pemerintahan, Pertahanan & 0,70 & 0,81 \\
& \& Jaminan Sosial Wajib & 0,42 & 0,38 \\
15 & Jasa Pendidikan & 0,75 & 0,67 \\
16 & Jasa Kesehatan \& Kegiatan Sosial & 0,26 & 0,01 \\
\hline 17 & Jasa lainnya & & \\
\hline
\end{tabular}

Sumber: hasil pengolahan data PDRB

Berdasarkan tabel 12. terlihat bahwa Provinsi Kepulauan Riau memiliki empat sektor yaitu sektor pertambangandan pengalian, sektor industri pengolahan, sektor pengadaan air dan sektor konstruksi. Potensi kawasan industri yang ada di Kota Batam membuat Provinsi Kepulauan Riau cukup unggul dalam sektor industri. Pandemi Covid 19 tidak merubah komposisi sektor unggulan di Provinsi Kepulauan Riau. Meskipun hasil dari analisis LQ memiliki sedikit perbedaan namun belum merubah kategori.

\section{SIMPULAN, KETERBATASAN, SARAN DAN REKOMENDASI}

\section{Simpulan}

Teori basis ekonomi mengedepankan ekspor sebagai ujung tombak pertumbuhan ekonomi suatu wilayah. Komoditas ekspor hanya memungkinkan berasal dari sektor pertanian, sektor pertambangan dan sektor industri pengolahan. Keunggulan komparatif ketiga sektor tersebut menjadi lebih penting dibandingkan sektor lainnya. Wilayah Sumatera secara umum memiliki keunggulan di sektor pertanian dan sektor pertambangan. Jika dilihat menurut provinsi, hampir seluruh provinsi di regional Sumatera memiliki keunggulan komparatif di sektor pertanian (hanya Provinsi Kepulauan Riau yang tidak memiliki keunggulan komparatif di sektor pertanian). Hanya terdapat tiga provinsi yang memiliki keunggulan komparatif di sektor pengolahan yaitu Provinsi Riau, Provinsi Kepulauan Bangka Belitung, dan Provinsi Kepulauan Riau. Hal ini menunjukkan industri pengolahan di regional Sumatera belum berkembang atau masih kalah dibandingkan daerah lainnya.

\section{Keterbatasan}

Penelitian ini memiliki keterbatasan dalam penyajian sektor. Badan Pusat Statistik dalam merilis PDRB triwulanan hanya menyajikan dalam level sektor besar saja, sehingga tidak bisa dihitung analisis LQ menurut subsektor maupun komoditas setiap sektornya.

\section{Saran dan Rekomendasi}

Berdasarkan hasil pembahasan dalam penelitian ini maka disampaikan beberapa saran dan rekomendasi sebagai berikut:

1. Provinsi di regional Sumatera yang memiliki keunggulan komparatif di sektor industri pengolahan masih sangat sedikit, padahal sumber daya/ bahan baku untuk menunjang 
sektor industri cukup tersedia yang berasal dari sektor pertanian maupun pertambangan.

2. Industri pengolahan yang cocok untuk dikembangkan di regional Sumatera adalah industri berbasis pertanian. Industri pengalengan ikan, pengepakan sayuran, peningkatan hasil perkebunan menjadi barang siap konsumsi merupakan contoh kegiatan industri di wilayah Sumatera yang masih bisa dikembangkan.

3. Mengingat hampir seluruh provinsi di regional Sumatera memiliki keunggulan komparatif sektor pertanian, maka sinergi antar provinsi di regional Sumatera bisa dilakukan dengan koordinasi pengiriman hasil pertanian ke wilayah regional lain menggunakan kapal. Koordinasi antar provinsi bisa mengurangi biaya operasional kapal karena muatan barang akan lebih optimal jika dibandingkan masing-masing provinsi mengirimkan barang sendiri ke wilayah lain.

\section{DAFTAR PUSTAKA}

Adhitama, R. (2012). Pengembangan Sektor-Sektor Ekonomi Di Tiap Kecamatan Di Kabupaten Magelang. Economics Development Analysis Journal, 1(2). https://doi.org/10.15294/edaj.v1i2.483

Alhaq, Q. (2017). Sektor Basis Ekonomi Pertanian Di Provinsi Riau (Periode 1997-2015). Jom Fekon, 4(1), 226-239. https://doi.org/10.1016/j.sbspro.2015.04.758

Astuti, H., \& Sumarlin. (2013). Analisis Komoditas Unggulan Tanaman Pangan Dan Kinerja Terhadap Pembangunan Pertanian Di Kabupaten Lampung Barat. Jurnal Kelitbangan, 03(01).

Bangun, R. H. (2018). Analisis Prioritas Pembangunan Wilayah Berdasarkan Sektor Produk Domestik Regional Bruto Kabupaten Tapanuli Tengah-Sumatera Utara. Jurnal Litbang Sukowati : Media Penelitian dan Pengembangan, 2(1), 19-35. https://doi.org/10.32630/sukowati.v2i1.38

BPS. (2020). Berita resmi statistik. In Berita Resmi Statistik. Diambil dari https://www.bps.go.id/pressrelease/2020/08/05/1737/-ekonomi-indonesia-triwulanii-2020-turun-5-32-persen.html

CNBC Indonesia. (2020). 44 Negara Resmi Resesi, Ekonomi Eropa Terparah. Diambil 10 September 2020, dari CNBC Indonesia website: https://www.cnbcindonesia.com/market/20200909091449-17-185427/44-negararesmi-resesi-ekonomi-eropa-terparah

CNN. (2020). Jokowi Resmikan Tol Sibanceh, Jalan Tol Pertama di Aceh. Diambil 10 September 2020, dari CNN website: Jokowi Resmikan Tol Sibanceh, Jalan Tol Pertama di Aceh

Faisal. (2014). Analisis Sektor Unggulan Perekonomian Kota Banda Aceh. Jurnal Ekonomi dan Kebijakan Publik Indonesia, 1(1), 8-15.

Glasson, J. (1990). Pengantar Ekonomi Regional (Terjemahan). Jakarta: LPFEUI. Imelia. (2011). Analisis Ekonomi Antar Wilayah di Provinsi Jambi. Jurnal Paradigma 
Ekonomika, 1(4), 62-72.

Karunia, A., \& Faidah, Y. A. (2017). Strategi Pengembangan Wilayah Melalui Pemetaan Daya Saing Ekonomi Kawasan Karesidenan Pekalongan. Jurnal AKSI, 1, 1-10.

Martadona, L., \& Leovita, A. (2019). Peranan Komoditas Unggulan Tanaman Pangan

Terhadap Pembangunan Ekonomi Wilayah Propinsi Sumatera Barat. Tata Loka, 21, 328-334.

Mustafa, Z. (1998). Pengantar Statistik Deskriptif (Kedua). Yogyakarta: EKONISIA Fakultas Ekonomi UII.

Nugrohadi, I. A. W., Devi, A., \& Rusydiana, A. S. (2015). Analisis Tinjauan Dan Posisi Daya Saing Perikanan Kabupaten Natuna Melalui Pendekatan LQ (Location Quotient), SSA (Shift Share Analysis) dan RCA (Revealed Comparative Advantage). Jurnal Administrasi dan Manajemen, 5(1), 201-211.

Nur, I., Mulatsih, S., \& Asmara, A. (2013). Analisis Struktur Perekonomian Dan Faktor-Faktor Yang Memengaruhi Pertumbuhan Ekonomi Sumatera Selatan. Jurnal Ekonomi Dan Kebijakan Pembangunan, 2(1), 47-59. https://doi.org/10.29244/jekp.2.1.47-59

Nurlina, N., Andiny, P., \& Sari, M. (2019). Analisis Sektor Unggulan Aceh Bagian Timur. Jurnal Samudra Ekonomi dan Bisnis, 10(1), 23-37. https://doi.org/10.33059/jseb.v10i1.1122

Pratama, A. R., Sukiyono, K., \& Arianti, N. N. (2017). Analysis of Agricultural Leading Subsector District/Cities in Bengkulu Province. Agric, 29(2), 121-136. https://doi.org/10.24246/agric.2017.v29.i2.p121-136

Sari, F. W. A. W., \& Bangun, R. H. (2019). Analisis Peranan Sektor Pertanian, Kehutanan dan Perikanan pada Perekonomian Kabupaten Deli Serdang. Journal Agroland, 26(3), 198211.

Tabrani, A. (2008). Analisis Sektor Unggulan Perekonomian Kabupaten Mandaling Natal Provinsi Sumatera Utara. Jurnal Sains dan Teknologi Indonesia, 10(1), 1-6. https://doi.org/http://dx.doi.org/10.29122/jsti.v10i1.787

Widiarsih, D. (2016). Analisa Potensi Ekonomi Daerah di Provinsi Kepulauan Bangka Belitung Analysis of economic potential in Bangka Belitung Islands. Jurnal Akuntansi \& Ekonomika, 6(02), 150-167.

Yulmardi, Y., \& Erfit, E. (2018). Daya saing sektor pertanian dalam mendorong pembangunan pertanian di Provinsi Jambi. Jurnal Paradigma Ekonomika, 13(2), 65-76. Diambil dari https://www.online-journal.unja.ac.id/paradigma/article/view/6748

\section{APPENDICES}

Tabel PDRB Atas Dasar Harga Konstan Kuartal 2 Tahun 2019 (trilliun rupiah)

\begin{tabular}{rlrrrrr}
\hline & Sektor & Aceh & Sumut & Sumbar & Riau & Jambi \\
\hline A & Pertanian, Kehutanan, \& Perikanan & 9,20 & 33,07 & 9,39 & 31,06 & 9,66 \\
B & Pertambangan \& Penggalian & 2,35 & 1,76 & 1,72 & 21,38 & 8,83 \\
C & Industri Pengolahan & 1,67 & 23,98 & 3,86 & 37,21 & 3,90 \\
D & Pengadaan Listrik, Gas & 0,05 & 0,18 & 0,05 & 0,08 & 0,02 \\
\hline
\end{tabular}




\begin{tabular}{|c|c|c|c|c|c|c|}
\hline $\mathrm{E}$ & Pengadaan Air & 0,01 & 0,13 & 0,04 & 0,02 & 0,05 \\
\hline $\mathrm{F}$ & Konstruksi & 2,66 & 17,05 & 3,97 & 10,49 & 2,69 \\
\hline G & $\begin{array}{l}\text { Perdagangan Besar \& Eceran, \& Reparasi } \\
\text { Mobil \& Sepeda Motor }\end{array}$ & 5,27 & 24,00 & 6,91 & 12,25 & 3,81 \\
\hline $\mathrm{H}$ & Transportasi \& Pergudangan & 2,39 & 6,40 & 5,36 & 1,1 & 1,19 \\
\hline 1 & Penyediaan Akomodasi \& Makan Minum & 0,46 & 3,27 & 0,49 & 0,6 & 0,42 \\
\hline J & Informasi \& Komunikasi & 1,15 & 3,81 & 3,22 & 1,19 & 1,39 \\
\hline K & Jasa Keuangan & 0,57 & 3,77 & 1,18 & 1,13 & 0,79 \\
\hline L & Real Estate & 1,38 & 5,67 & 0,84 & 1,16 & 0,55 \\
\hline $\mathrm{M}, \mathrm{N}$ & Jasa Perusahaan & 0,22 & 1,23 & 0,19 & 0,01 & 0,39 \\
\hline 0 & $\begin{array}{l}\text { Administrasi Pemerintahan, Pertahanan \& } \\
\text { Jaminan Sosial Wajib }\end{array}$ & 3,02 & 4,39 & 2,49 & 2,17 & 1,30 \\
\hline$P$ & Jasa Pendidikan & 0,89 & 2,71 & 1,70 & 0,63 & 1,21 \\
\hline Q & Jasa Kesehatan \& Kegiatan Sosial & 1,02 & 1,28 & 0,61 & 0,25 & 0,44 \\
\hline \multirow[t]{2}{*}{$\mathrm{R}, \mathrm{S}, \mathrm{T}, \mathrm{U}$} & Jasa lainnya & 0,48 & 0,70 & 0,78 & 0,67 & 0,40 \\
\hline & Jumlah & 32,79 & 133,39 & 42,80 & 121,40 & 37,03 \\
\hline
\end{tabular}

Tabel PDRB Atas Dasar Harga Konstan Kuartal 2 Tahun 2019 (trilliun rupiah) (lanjutan)

\begin{tabular}{|c|c|c|c|c|c|c|}
\hline & Sektor & Sumsel & $\begin{array}{c}\text { Bengku } \\
\text {-lu }\end{array}$ & Lampung & Babel & Kepri \\
\hline A & Pertanian, Kehutanan, \& Perikanan & 13,25 & 3,17 & 18,20 & 2,51 & 1,41 \\
\hline B & Pertambangan \& Penggalian & 17,69 & 0,39 & 3,50 & 1,66 & 5,87 \\
\hline C & Industri Pengolahan & 14,83 & 0,70 & 11,77 & 2,94 & 17,10 \\
\hline D & Pengadaan Listrik, Gas & 0,09 & 0,01 & 0,11 & 0,01 & 0,41 \\
\hline $\mathrm{E}$ & Pengadaan Air & 0,09 & 0,02 & 0,06 & 0,00 & 0,06 \\
\hline $\mathrm{F}$ & Konstruksi & 9,11 & 0,53 & 5,82 & 1,18 & 8,47 \\
\hline G & $\begin{array}{l}\text { Perdagangan Besar \& Eceran, \& Reparasi } \\
\text { Mobil \& Sepeda Motor }\end{array}$ & 8,27 & 1,86 & 7,66 & 1,94 & 3,92 \\
\hline $\mathrm{H}$ & Transportasi \& Pergudangan & 1,61 & 0,94 & 3,33 & 0,51 & 1,11 \\
\hline I & Penyediaan Akomodasi \& Makan Minum & 1,15 & 0,20 & 0,91 & 0,33 & 1,09 \\
\hline J & Informasi \& Komunikasi & 2,7 & 0,54 & 2,99 & 0,31 & 1,16 \\
\hline K & Jasa Keuangan & 1,83 & 0,34 & 1,19 & 0,25 & 1,24 \\
\hline L & Real Estate & 2,5 & 0,51 & 1,84 & 0,42 & 0,63 \\
\hline $\mathrm{M}, \mathrm{N}$ & Jasa Perusahaan & 0,09 & 0,26 & 0,08 & 0,03 & 0,00 \\
\hline 0 & $\begin{array}{l}\text { Administrasi Pemerintahan, Pertahanan \& } \\
\text { Jaminan Sosial Wajib }\end{array}$ & 2,31 & 1,03 & 1,88 & 0,79 & 1,09 \\
\hline $\mathrm{P}$ & Jasa Pendidikan & 2,02 & 0,72 & 1,78 & 0,34 & 0,60 \\
\hline Q & Jasa Kesehatan \& Kegiatan Sosial & 0,51 & 0,20 & 0,59 & 0,17 & 0,40 \\
\hline \multirow[t]{2}{*}{$R, S, T, U$} & Jasa lainnya & 0,63 & 0,10 & 0,57 & 0,11 & 0,22 \\
\hline & Jumlah & 78,68 & 11,51 & 62,28 & 13,52 & 44,77 \\
\hline
\end{tabular}

Tabel PDRB Atas Dasar Harga Konstan Kuartal 2 Tahun 2020 (trilliun rupiah)

\begin{tabular}{clccccc}
\hline & Sektor & Aceh & Sumut & Sumbar & Riau & Jambi \\
\hline A & Pertanian, Kehutanan, \& Perikanan & 9,25 & 33,54 & 9,44 & 32,27 & 9,75 \\
B & Pertambangan \& Penggalian & 2,90 & 1,69 & 1,65 & 19,85 & 8,72 \\
C & Industri Pengolahan & 1,61 & 23,79 & 3,78 & 37,74 & 3,83 \\
\hline
\end{tabular}




\begin{tabular}{|c|c|c|c|c|c|c|}
\hline \multicolumn{2}{|r|}{ Sektor } & \multirow{2}{*}{$\begin{array}{l}\text { Aceh } \\
0,06\end{array}$} & \multirow{2}{*}{$\begin{array}{c}\text { Sumut } \\
0,18\end{array}$} & \multirow{2}{*}{$\begin{array}{c}\text { Sumbar } \\
0,04\end{array}$} & \multirow{2}{*}{$\begin{array}{l}\text { Riau } \\
0,09\end{array}$} & \multirow{2}{*}{$\begin{array}{r}\text { Jambi } \\
0,02\end{array}$} \\
\hline $\mathrm{D}$ & Pengadaan Listrik, Gas & & & & & \\
\hline $\mathrm{E}$ & Pengadaan Air & 0,01 & 0,13 & 0,04 & 0,02 & 0,05 \\
\hline $\mathrm{F}$ & Konstruksi & 3,30 & 16,21 & 3,76 & 9,97 & 2,57 \\
\hline G & $\begin{array}{l}\text { Perdagangan Besar \& Eceran, \& Reparasi } \\
\text { Mobil \& Sepeda Motor }\end{array}$ & 4,78 & 23,14 & 6,68 & 9,55 & 3,65 \\
\hline $\mathrm{H}$ & Transportasi \& Pergudangan & 1,18 & 5,10 & 3,79 & 0,68 & 0,89 \\
\hline 1 & Penyediaan Akomodasi \& Makan Minum & 0,39 & 2,79 & 0,33 & 0,35 & 0,35 \\
\hline $\mathrm{J}$ & Informasi \& Komunikasi & 1,35 & 4,01 & 3,59 & 1,33 & 1,57 \\
\hline $\mathrm{K}$ & Jasa Keuangan & 0,60 & 3,68 & 1,16 & 1,17 & 0,82 \\
\hline $\mathrm{L}$ & Real Estate & 1,35 & 5,69 & 0,86 & 1,17 & 0,52 \\
\hline $\mathrm{M}, \mathrm{N}$ & Jasa Perusahaan & 0,20 & 1,13 & 0,18 & 0,00 & 0,36 \\
\hline 0 & $\begin{array}{l}\text { Administrasi Pemerintahan, Pertahanan \& } \\
\text { Jaminan Sosial Wajib }\end{array}$ & 2,94 & 4,53 & 2,39 & 2,04 & 1,25 \\
\hline $\mathrm{P}$ & Jasa Pendidikan & 0,91 & 2,73 & 1,74 & 0,65 & 1,26 \\
\hline Q & Jasa Kesehatan \& Kegiatan Sosial & 0,95 & 1,23 & 0,64 & 0,29 & 0,446 \\
\hline $\mathrm{R}, \mathrm{S}, \mathrm{T}, \mathrm{U}$ & Jasa lainnya & 0,45 & 0,65 & 0,63 & 0,38 & 0,366 \\
\hline & Jumlah & 32,22 & 130,23 & 40,70 & 117,56 & 36,42 \\
\hline
\end{tabular}

Tabel PDRB Atas Dasar Harga Konstan Kuartal 2 Tahun 2020 (trilliun rupiah) (lanjutan)

\begin{tabular}{|c|c|c|c|c|c|c|}
\hline & Sektor & Sumsel & $\begin{array}{l}\text { Bengku } \\
-l u\end{array}$ & Lampung & Babel & Kepri \\
\hline$A$ & Pertanian, Kehutanan, \& Perikanan & 13,44 & 3,24 & 18,50 & 2,66 & 1,32 \\
\hline B & Pertambangan \& Penggalian & 17,03 & 0,38 & 3,42 & 1,47 & 5,63 \\
\hline C & Industri Pengolahan & 14,81 & 0,68 & 10,30 & 2,80 & 17,33 \\
\hline $\mathrm{D}$ & Pengadaan Listrik, Gas & 0,1 & 0,01 & 0,11 & 0,01 & 0,39 \\
\hline$E$ & Pengadaan Air & 0,09 & 0,03 & 0,06 & 0,00 & 0,05 \\
\hline $\mathrm{F}$ & Konstruksi & 8,99 & 0,52 & 5,69 & 1,13 & 7,50 \\
\hline G & $\begin{array}{l}\text { Perdagangan Besar \& Eceran, \& Reparasi } \\
\text { Mobil \& Sepeda Motor }\end{array}$ & 7,63 & 1,78 & 6,87 & 1,74 & 3,49 \\
\hline $\mathrm{H}$ & Transportasi \& Pergudangan & 1,43 & 0,83 & 2,89 & 0,35 & 0,41 \\
\hline I & Penyediaan Akomodasi \& Makan Minum & 0,94 & 0,20 & 0,84 & 0,30 & 0,46 \\
\hline $\mathrm{J}$ & Informasi \& Komunikasi & 3,02 & 0,56 & 3,32 & 0,36 & 1,36 \\
\hline $\mathrm{K}$ & Jasa Keuangan & 1,8 & 0,38 & 1,22 & 0,22 & 1,17 \\
\hline $\mathrm{L}$ & Real Estate & 2,51 & 0,52 & 1,81 & 0,43 & 0,57 \\
\hline $\mathrm{M}, \mathrm{N}$ & Jasa Perusahaan & 0,09 & 0,25 & 0,08 & 0,03 & 0,00 \\
\hline $\mathrm{O}$ & $\begin{array}{l}\text { Administrasi Pemerintahan, Pertahanan \& } \\
\text { Jaminan Sosial Wajib }\end{array}$ & 2,41 & 1,03 & 1,98 & 0,76 & 1,19 \\
\hline$P$ & Jasa Pendidikan & 2,04 & 0,73 & 1,86 & 0,34 & 0,53 \\
\hline Q & Jasa Kesehatan \& Kegiatan Sosial & 0,61 & 0,21 & 0,61 & 0,16 & 0,37 \\
\hline \multirow[t]{2}{*}{$\mathrm{R}, \mathrm{S}, \mathrm{T}, \mathrm{U}$} & Jasa lainnya & 0,68 & 0,10 & 0,51 & 0,09 & 0,01 \\
\hline & Jumlah & 77,62 & 11,45 & 60,06 & 12,85 & 41,79 \\
\hline
\end{tabular}

